\title{
Scientific attitude - some psychometric considerations
}

\author{
Dr. Rajib Mukhopadhyay \\ Department of Education, St Xavier's College, Kolkata, West Bengal, India.
}

\begin{abstract}
In the present context of the revolution of science and technology, imortance of science education is being recognised more and more. In fact, achievement in science has become one of the major quality parameters of students. Among several determinants of achievement in science, scientific attitude is an important one. Students' scientific attitude should be a major concern of science teacher. In particular, the knowledge of different operational dimensions of scientific attitude and its measument might enable a science teacher to identify inclination of science learners towards different endeavours in science. This psychometric consideration of scientific attitude is focal area of the present study. The study has explained the term 'attitude' in general, and 'scientific attitude', in particular. Various operational dimensions of the construct have also been discussed with reference to a detailed review of related literature. Emphasis has been given to the scientific attitude of secondary school learners. Different available tools have also been reviewed. A tool having sound psychometric basis and siutable for the present purpose has also been identified in light of this review, which may be used by a science teacher in secondary science classroom.
\end{abstract}

Key words: scientific attitude, escondary learners, operational dimensions, review of related tools.

\section{Introduction}

In the context of revolution of science and technology, importance of science education is being recognized more and more. Itshould be considered as an integral part of school education, as recommended by N.P.E(1986). Science strengthens commitments of man to free enquiry and search for truth as its heighest beauty and obligation (Celenti, 1988). Therefore the study of science imparts training in scientific method developing scientific attitude of learners. This is the quality which ensures sustainable development of an individual as well as the nation which is becoming more and more scientific gradually (Rao, 1996).

Development of scientific attitude is one among the most important outcomes of science education (Carin, 1997). Even it is important equally as cognitive aspects of science education. Scientific attitude encourages questioning mind and a spirit of enquiry. Thereforewithout this, studies of science will only mean acceptance of dogma and will never led to development of proper orientation towards various scientific endeavors (Lacrose \& Wisconsin, 2007). Whereas in case of lacking of it,any amount of knowledge in science will also contribute little to national development and to the process of social change, as well.

Not only this, scientific attitude is one among the major determinants of students' achievement in science - which has become a major quality parameter of a student living in the present scientific society (Abell \& Lederman, 2007). Now-a-days rate of admission of students in science courses is increasing at a rapid rate. Even parents are also driven strongly by the urge of admitting their children in science courses. But a mere enrollment in science courses will not result any ultimate benefit of learners unless students' science learning is made effectiveby developing adequate scientific attitude through effective science teaching (Moore \& Foy, 1997). Therefore scientific attitude is one among the major areas of concern of a teacher in the classroom situation in general. Particularly teachers' clear understanding of the conceptual framework of scientific attitude, way of measuring students' scientific attitude in view of various associated criterion and taking suitable measures to nurture the quality subsequently are very essential to ensure a quality science education..

This also necessitates extensive research work in science education, specifically in the area of scientific attitude of school learners.Few studies are available in this area. But studies are very much scattered, as well as isolated (Peters \& Stout, 2006). A comprehensive and systematic review of the existing works are extremely inadequate. This also leads to selection of the present study. Following questions arise in the mind of present researcher in this regard.

- How is scientific attitude is explained and defined by researchers?

- What are various psychometric dimensions of it?

- Whether available tools on scientific attitude are adequate and are constructed in view of all the essential psychometric considerations?

Present study is an attempt of finding answer of all these questions. It aims at particularly to explain the conceptual framework of attitude in general, and scientific attitude in particular; to discuss various operational dimension of scientific attitude as suggested by different researchers, and also to review the related tools in 
details. These are discussed step by step in following section with special reference to secondary school learners.

\section{Conceptual Framework - Attitude, Scientific Attitude}

An attitude is a general and enduring positive or negative feeling about some person, object or issue (Jones and Batts, 1983). "Scientific attitudes are attributes of an individual who not only behave outwardly in desirable way towards any scientific endeavor but also understand why they act as they do so", defined by Rao (1996).

Scientific attitude has three basic components: belief, feeling and action. Belief is the cognitive basis of scientific attitude, which provides a learner several scientific information of scientific phenomenon, eminent scientists, scientific inventions etc.

Central component of scientific attitude is the feeling towards the belief. Effective science teaching, personality of science teacher, teaching- learning environment etc. plays a major role through which the belief of a learner is converted into his/her feeling towards it. Feeling is associated with emotion, on the basis of which a science learner develops his/her opinion.

Third component of scientific attitude is action or behavioral component which is mostly conative. It is the tendency of a science learner to act towards his/her scientific belief in accordance with feeling or opinion. For one reason or another, a people do not or cannot always act the way they feel, but tendency is there. Scientific attitude, according to Rao (1996), represents the motivation which converts the knowledge about scientific facts and skills in the use of scientific methods into action and refers to a willingness to use scientific procedures and methods in each step of own life of an individual. It is explained by Abell and Lederman (2007) as an attitude to scientific ideas and information, particular way of evaluating them for transferring, in day to day experiences.

\section{Scientific Attitude: Various Psychometric Considerations}

Sood and Sanadhyay (1978, in Rao : 1996) measured scientific attitude in relation to rationality, openmindedness, curiosity, aversion to superstition, objectivity of intellectual belief, and suspended judgment.

Cilenti (1988) considered - curiosity, modesty, skepticism, truthfulness, open-mindedness, and determination. Rao, et. al (1989) state the most important scientific attitudes are open-mindedness, criticalmindedness, respect for evidence, suspended judgement, intellectual honesty, willingness to change opinion, search for truth, curiosity, rational thinking, etc. Simpson (1994, in Osborne \& Collins:2003 ) grouped scientific attitude into the categories - willingness of knowing and learning, enquiry and desire for everything, correcting and searching data, willingness to prove truthfulness, respect to logic, and, thinking for pre and post results.Carim (1997) considered curiosity, dependence on proof, skepticism, cooperation of others, respect for different approaches etc.Karasar (1999, in Aktamis \& Ergin: 2008) considered open-mindedness, being modest for making mistakes, giving chance to different probabilities in judgment etc. Peter and Stout (2006) considered five groups presenting scientific attitude viz. curiosity, persistence, accepting uncertainty, inventiveness, and critical thinking. The last two dimensions seem to be novel, for not being considered by other researchers in this relation. Lacrose and Wisconsin (2007) considered - conviction of universal bias and preference towards cause and relation, sensitivity and curiosity, habit of delayed response holding views tentatively for suitable reflection, habit of weighing evidence, respect for another point of view, and willingness to be convinced by evidence etc.

Studies so far discussed, have considered scientific attitude in relation with different attributes, which are the characteristics of a scientist. Another trend is also found in this connection. Aktamis and Ergin (2008) considered various 'actions performed by' or 'behavior of a person' towards different aspects of science as attitude towards scientific knowledge, scientific method, activity of scientist and science career. Scientific attitude have three basic components i.e. belief, feeling and action. Belief of a person and his feeling towards science, scientists on scientific invention etc. leads him/her to act accordingly. Aktamis and Ergin (2008) emphasized to the third component of scientific attitude. This 'action' or 'behaviour' components have also been emphasized by Mandilla(1988), Gohit and Sreedevi (2009) etc. in relation to scientific attitude.

Measures emphasizing on 'attributes' are frequently used to mean 'scientific attitudes', whereas 'action and behaviour' oriented measures use the term ' attitude towards science' etc. (Richardson : 1996, in Abell\& Lederman: 2007).

The attempts so far discussed, considered scientific attitude having a single, uni-dimensional construct in relation to several attributes or behaviors and add the individual scores on each attribute or behaviour to find out the total score on 'scientific attitude'. Gardner (1975), Jones and Batts (1983) considered multidimensional construct of scientific attitude. Gardner (1975) referred to 'attitude towards science' and 'scientific attitude' as two separate dimensions and considered scoring on each dimension separately, without considering a single common score for measuring a unique scientific attitude. Jones and Batts(1983) proposed a four dimensional construct of scientific attitude, considering the dimensions as independent measures. Though multidimensional 
construct is recognized, but most of the available instruments consider 'scientific attitude' having a unidimensional construct, emphasizing on several scientific attributes as the measures.

\section{Review On Related Tools}

Major features of few available tools widely used by researchers are shown in the folling table.

TABLE1: Major Features of Few Available Tools on Scientific Attitude

\begin{tabular}{|c|c|c|c|c|}
\hline Test & Sample & Sub-dimensions & Reliability & Validity \\
\hline $\begin{array}{l}\text { 1.Scientific Attitude } \\
\text { Scale (SAS: Sood } \\
\text { and Sanadhya, } \\
(1978) \text {, adopted by } \\
\text { Rao (1996) }\end{array}$ & $\begin{array}{l}\text { Secondary } \\
\text { students }\end{array}$ & $\begin{array}{l}\text { Rationality, Open mindedness, Curiosity, } \\
\text { Aversion to superstition, Objectivity of } \\
\text { intellectual belief, Suspended judgment }\end{array}$ & $\begin{array}{l}\text { Split-Half } \\
(\mathrm{r}=0.88 \\
\mathrm{p}<0.01)\end{array}$ & $\begin{array}{l}\text { 1.Intrinsic (test-subtest, } \\
\text { subtest-subtest) } \quad(\mathrm{r}=0.62 \\
\text { to } 0.82, \mathrm{p}<0.01)\end{array}$ \\
\hline $\begin{array}{l}\text { 2. Attitude towards } \\
\text { Science Scale } \\
\text { (Aktamis and Ergin, } \\
\text { 2008) }\end{array}$ & $\begin{array}{l}\text { Lower } \\
\text { secondary } \\
\text { (VIII) }\end{array}$ & $\begin{array}{l}\text { Attitude towards- } \\
\text { 1.Scientific knowledge } \\
\text { 2.Scientific career } \\
\text { 3. Scientists }\end{array}$ & $\begin{array}{c}\text { Internal } \\
\text { consistency } \\
(\text { alpha }=0.88)\end{array}$ & $\begin{array}{l}\text { 1.Content validity } \\
\text { (satisfactory) } \\
\text { 2.Intrinsic validity (item- } \\
\text { total)(significant) }\end{array}$ \\
\hline $\begin{array}{l}\text { 3.Scientific Attitude } \\
\text { Scale (SAS: Gohit } \\
\text { and Sredevi, 2008) }\end{array}$ & $\begin{array}{l}\text { Secondary } \\
\text { students }\end{array}$ & $\begin{array}{l}\text { Curiosity, Rationality, Open mindedness, } \\
\text { Objectivity, Suspended, Judgment, Freedom, } \\
\text { Superstition, Perseverance }\end{array}$ & $\begin{array}{l}\text { Test-retest } \\
(\mathrm{r}=0.66 \\
\mathrm{p}<0.01)\end{array}$ & $\begin{array}{l}\text { Content validity } \\
\text { (satisfactory) }\end{array}$ \\
\hline $\begin{array}{lr}\text { 4.Attitude } & \text { towards } \\
\text { Scientific } & \text { Scale } \\
\text { (Gohit and } & \text { Sredevi, } \\
\text { 2008) } & \end{array}$ & $\begin{array}{l}\text { Secondary } \\
\text { level }\end{array}$ & $\begin{array}{l}\text { Attitude towards- } \\
\text { 1.Using scientific materials } \\
\text { 2.Perceived comfort and discomfort related to } \\
\text { science classroom } \\
\text { 3.Learning science content } \\
\text { 4.Reading or talking about science related topic } \\
\text { 5.Viewing science programme on TV/Film }\end{array}$ & $\begin{array}{c}\text { Test-retest } \\
(\mathrm{r}=0.65, \mathrm{p}<0.01 \\
)\end{array}$ & $\begin{array}{ll}\text { Content } & \text { validity } \\
\text { (Satisfactory) } & \end{array}$ \\
\hline $\begin{array}{l}\text { 5.Scientific Attitude } \\
\text { Inventory (SAI: } \\
\text { Lichtenstien, 2008)- } \\
\text { the revised version } \\
\text { SAI, standardized by } \\
\text { Moore and Sutman } \\
(1981)\end{array}$ & $\begin{array}{l}\text { Secondary } \\
\text { students }\end{array}$ & $\begin{array}{l}\text { Attitude } \\
\text { 1. Forconsidering science as a subject } \\
\text { for understanding and explaining } \\
2 . \quad \text { For considering science as dynamic } \\
\text { in nature } \\
\text { 3.Towards scientists }\end{array}$ & $\begin{array}{c}\text { Internal } \\
\text { consistency }(\mathrm{a}= \\
0.59 \text { to } 0.85 \text { for } \\
\text { individual sub } \\
\text {-dimensions) }\end{array}$ & $\begin{array}{l}\text { Construct } \\
\text { using validity - } \\
\text { factor confirmatory } \\
\text { (Necessity for further } \\
\text { investigation of validity } \\
\text { - as reported) }\end{array}$ \\
\hline $\begin{array}{l}\text { 6.ScientificAttitude } \\
\text { Scale: Yasar, et. al. } \\
\text { 2009) }\end{array}$ & $\begin{array}{l}\text { Lowersecond } \\
\text { ary (Related } \\
\text { to sense, } \\
\text { thoughts and } \\
\text { behaviours } \\
\text { devoted to } \\
\text { science and } \\
\text { technology } \\
\text { course }\end{array}$ & $\begin{array}{l}\text { Curiosity, Critical thinking, Proof dependence, } \\
\text { Persistency, Co-operation, Objectivism, } \\
\text { Acceptance of uncertainties }\end{array}$ & $\begin{array}{c}\text { Internal } \\
\text { consistency } \\
(\text { alpha }=0.83)\end{array}$ & 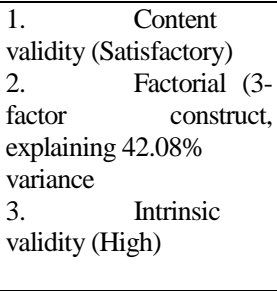 \\
\hline
\end{tabular}

Study reveals the following points:

1.Poor psychometric property is found in Scale no.-5.

2. Scale no. 2 and 6 are valid for lower secondary group.

3. Content validity were only estimated in scale no. 3 and 4.

Results of review reveal that scale no. 1 is appropriate for the present sample. Sound psychometric property, availability along with detailed manual, easy and readable items using gender and culturefair language, adaptation of the same by other researcher (Rao, 1996) etc. lead to its selection by many researchers.

Brief description of the scale is as follows, though some of its main features have already been shown in the table (Table 1) mentioned earlier.

Scientific Attitude Scale standardized by Sood and Sanadhya (1978) consists of 36 items (statements) together, having been constructed from six different dimensions (6 statements for each dimension), as mentioned in the table. It is a Likert-type scale. Five options (strongly agree, agree, neutral, disagree, strongly disagree) are there for each of the statements. Among these, 18 statements are of positive polarity (score 4 for strongly agree, score 3 for agree, 2 for neutral, 1 for disagree, 0 for strongly disagree), and remaining 18 are of negative polarity (reverse scoring). Scores for each individual statement are to be added to obtain the total score on scientific attitude. Rao (1996) adopted the scale in his study, estimated its reliabilities and validities over a group of 200 Indian sample (secondary students). Split-half method was used for estimating coefficient of reliability of the entire test, as well as for its each individual dimension. For the entire test, coefficients was found to be 0.86 ; and $0.76,0.86,0.84,0.80,0.73,0.82$ - respectively for the dimensions-rationality, curiosity, open-mindedness, aversion to suspension, objectivity of intellectual belief, and suspended judgment. Coefficient of intrinsic validity was also estimated by Rao (1996), considering sub-scale-sub-scale, and sub-scale-total correlation. Coefficients of intrinsic validity (sub-scale-total correlation) estimated were $0.62,0.76,0.80,0.81$, 
0.85 and 0.82 respectively for different dimensions. Validity coefficients, in case of sub-scale-sub-scale correlation were found to vary from 0.31 to 0.63 (Rao, 1996)

\section{Conclusion}

The review therefore reveals that Scientific Attitude Scale (SAS: Sood and Sanadhya :1978) may be used by a teacher in science classroom for measuring secondary students' scientific attitude. Following measures may be taken for its qualitative improvement.

The test may be standardised on the basis of response of a larger sample group. More number of relevant sub dimensions may be incorporated reducing the number of items under each dimension proportionately. Internal consistency reliability of the test (in terms of cron back alpha- coefficient) may also estimated. Factor analysis may also be conducted to estimate its factorial validity. A norm (percentile, stanine etc.) may also be established to ensure better interpretability of the scores.

\section{Reference}

[1] Abell, S.K. \& Lederman, N.G.(2007). Handbook of Research on Science Education, Lawrence Erlbaum Asssociates:N.Jercy.

[2] Aktamis, H. \& Ergin, O. (2008). The effect of scientific process skill education on students scientific creativity, scientific attitude and academic achievement, Asia Pacific Forum on Science Learning and Teaching, 9(1), Article - 4.

[3] Carin, M. (1997). Teaching modern science. Upper Saddle River, NJ: Merrill/ Prentice Hall. In S.Yasar, \& S.S. Anagun. (Eds). Scale for measuring Scientific Attitude, Turkish Journal of Science Education,2009, 6(2).

[4] Çilenti, K. (1988). Fen bilgisi öretimi. Özel öretim yöntemleri. Ed. Bekir Özer, Eskiehir: Anadolu Üniversitesi Yaymlar, In S.Yasar, \& S.S. Anagun, (Eds). Scale for measuring Scientific Attitude, Turkish Journal of Science Education, 2009, 6(2).

[5] Gardner, P.L. (1995). Measuring attitude to science: Unidimensionality and internal consistency revisited, Research in science Education, 25(3), 283-289.

[6] Gohit, R. K. \& Sreedevi, K.V. (2008), Scientific Attitude Scale, Constructivism in Science Education, Discovery Publishing House.

[7] Jones, B.\& Batts B. (1983) Development of set of scales to measure selected scientific attitude, Research in Science Education, 13(1), 133-140.

[8] Lacrose, A.G. \& L. Wisconsin.(2007). Test for Measuring Scientific Attitude of 12-th standard students. School Science and Mathematics.

[9] Lichtenstein, M.J. (2008). Psychometric reevaluation of the Scientific Attitude Inventory-revised, Journal of Research in Science Teaching. 45(5), pp- 600-616

[10] Mandila, S.S. (1988). Attitudes of Secondary stage students towards science curriculum and its relationship with achievement motivation. Ph.D. Dissertation, University of Rajasthan. In M.B. Buch (Eds.), fifth survey of Educational Research, N.C.E.R.T.: New Delhi.

[11] Moore, R. W. \& Foy, R. L. H. (1997). The scientific attitudes inventory: A revision (SAI II). Journal of Research in Science Teaching, 34, 327-341.

[12] Omatoya, K.A., \& Olaleye, F.O. (2008). Affective Science Teaching: A Method to Enhance Qualitative Science Education in Nigeria. The Social Sciences: Medwell Journals, 3(4), 322-326. ISSN: 1818-6215.

[13] Osborne, J., Simon, S.\& Collins, S. (2003). Attitudes toward science: A review of the literature and its implication. International Journal of Science Education 25 (9), 1049-1079.

[14] Peters, J. M. \& Stout, D. L. (2006). Methods for teaching elementary school science (5 th ed.). Ohio: Merrill Prentice Hall.

[15] Rao, D.B.(1996 ).Scientific Attitude vis-à-vis Scientific Aptitude, Discovery Publishing House: N.Delhi.

[16] Rao, D.B., Rao, G. S., Aruna,S.\& Rathaiah,L. (1989). Scientific attitudes and personality traits of prospective science teachers. Progressive Educational Herald,3, 62-66.

[17] Yasar,S. \& Anagun, S.S., (2009). Reliability and Validity studies of the science teaching course- Scientific Attitude Scale, Journal of Turkish science education, 4 (2), Ekip. Ltd. 